\title{
DISTRIBUTION OF FISH ASSEMBLAGES IN LAJES RESERVOIR, RIO DE JANEIRO, BRAZIL
}

\author{
ARAÚJO, F. G. and SANTOS, L. N. \\ Laboratório de Ecologia de Peixes, Universidade Federal Rural do Rio de Janeiro, km 47, Antiga Rodovia \\ Rio-São Paulo, Seropédica, CEP 23851-970, Rio de Janeiro, RJ, Brazil \\ Correspondence to: Francisco Gerson Araújo, Laboratório de Ecologia de Peixes, Universidade Federal Rural do \\ Rio de Janeiro, km 47, Antiga Rodovia Rio-São Paulo, Seropédica, CEP 23851-970, Rio de Janeiro, RJ, Brazil, \\ e-mail: gerson@ufrrj.br \\ Received July 5, 2000 - Accepted October 16, 2000 - Distributed November 30, 2001
}

(With 6 figures)

\begin{abstract}
Spatial distribution of fish assemblages in Lajes Reservoir, a $30 \mathrm{~km}^{2}$ impoundment in Rio de Janeiro State (Lat. $22^{\circ} 42^{\prime}-22^{\circ} 50^{\prime}$ 'S ; Long. $43^{\circ} 53^{\prime}-44^{\circ} 05^{\prime} \mathrm{W}$ ) was assessed to detect patterns of available habitat use by the fish. A standardized monthly sampling program was carried out from January to December 1994 at three zones of the reservoir (upper, near tributary mouths; middle; and lower, near the dam). Fishes were caught by gillnets, ( $50 \mathrm{~m}$ long, $3 \mathrm{~m}$ height), with mesh ranging having from 25 to 45 $\mathrm{mm}$ between knots, submerged during 12 hours. A total of 5,089 fishes were collected comprising 15 species, 14 genera and 9 families. Loricariichthys spixii, Astyanax bimaculatus, Parauchenipterus striatulus, Astyanax fasciatus parahybae, Oligosarchus hepsetus, Rhamdia parahybae, Hypostomus affinis, and Geophagus brasiliensis were the most abundant species, each contributing above $1 \%$ of the total number. Loricariichthys spixii was the dominant species, contributing over $80 \%$ of total number and biomass. Fish abundance, number of species, and biomass were higher in the upper zone, but differences from this overall pattern were shown by some species. Loricariichthys spixii and Rhamdia parahybae were more abundant in the upper zone, while all other species showed no differences in their abundance among the zones. Seasonal environmental variables of temperature, $\mathrm{pH}$, transparency, and water level did not show a clear association with fish occurrence. Most fish used the different zones of the reservoir with no clear sign of spatial separation. High dominance of L. spixii, reduced abundance of reolific species Leporinus copelandii and Cyphocharax gilberti, and presence of introduced species such as Cichla monoculus and Tilapia rendalli are indications of antropic effects in the fish community.
\end{abstract}

Key words: reservoirs, fish community, freshwater fishes, spatial distribution, ichthyofauna.

\section{RESUMO}

\section{Distribuição da associação de peixes no Reservatório de Lajes, RJ}

A distribuição espacial da taxocenose de peixes do Reservatório de Lajes, um represamento de 30 $\mathrm{km}^{2}$ no Estado do Rio de Janeiro (Lat. $22^{\circ} 42^{\prime}-22^{\circ} 50^{\prime}$ S; Long. $43^{\circ} 53^{\prime}-44^{\circ} 05^{\prime}$ 'W), foi analisada visando detectar eventuais padrões de uso dos habitats disponíveis pelos peixes. Amostragens mensais padronizadas entre janeiro e dezembro de 1994 foram realizadas em três zonas do reservatório (alta, próxima à entrada de tributários, intermediária e baixa, próxima à barragem). Os peixes foram capturados com redes de espera (50 m comprimento por $3 \mathrm{~m}$ altura), com malhas variando de 25 a $45 \mathrm{~mm}$ entre nós adjacentes e tempo de permanência de 12 horas. Foi capturado um total de 5.089 peixes, compreendendo 15 espécies, 14 gêneros e 9 famílias. Loricariichthys spixii, Astyanax bimaculatus, Parauchenipterus striatulus, Astyanax fasciatus parahybae, Oligosarchus hepsetus, Rhandia parahybae, Hypostomus affinis e Geophagus brasiliensis foram as espécies mais abundantes, contribuindo individualmente com mais de $1 \%$ da abundância total. Loricariichthys spixii foi a espécie dominante, 
contribuindo com mais de $80 \%$ do número e biomassa total dos peixes. A zona alta apresentou maiores valores para número de indivíduos, espécies e biomassa, embora algumas espécies tenham demonstrado diferenças nesse padrão geral. Loricariichthys spixii e Rhamdia parahybae foram mais abundantes na zona alta, contudo não foram detectadas diferenças espaciais na abundância para as demais espécies. Não foram detectadas associações bem definidas entre as variáveis ambientais de temperatura, $\mathrm{pH}$, transparência e nível da água e a ocorrência de peixes. Em geral, a maioria dos peixes utiliza as diferentes zonas do reservatório sem indicações de separação espacial. A elevada dominância de $L$. spixii, a redução de espécies reolíficas, como Leporinus copelandii e Cyphocharax gilberti, e a presença de espécies introduzidas, como Cichla monoculus e Tilapia rendalli, são indicações de efeitos antrópicos na comunidade de peixes.

Palavras-chave: reservatórios, comunidade de peixes, peixes de água doce, distribuição espacial, ictiofauna.

\section{INTRODUCTION}

Most natural aquatic environments support characteristic fish assemblages which have developed over evolutionary time. In natural lakes, fish assemblages exhibit temporal and spatial patterns of species abundance and distribution related to the presence of aquatic macrophytes, water temperature, dissolved oxygen, competition, and predator-prey interactions (Keast, 1978). The creation of a new lake behind a hydroelectric dam provides a natural experiment by which to study how riverine species become adapted for lacustrine life, and how faunas change and new lacustrine communities are formed (Welcomme, 1979). Fish assemblages in most reservoirs include both native and introduced species in a non-naturally occurring habitat that is subject to fluctuation in depth or other human regulation. Such artificial assemblages have existed only briefly in evolutionary time, relative to those in naturally occurring habitats, and humans strongly influence their composition.

The Lajes Reservoir is one of the oldest impoundments for hydroelectric purposes in Brazil. It was built by damming small stream watershed collections, while most reservoirs in the same area dammed large rivers with low water retention time and marked longitudinal gradients. In Lajes Reservoir, on the other hand, there is no marked longitudinal gradient due to relatively small tributary contributions, forming a much more restricted habitat with no available lotic environment to allow fish migrations into and out of the lake. The question then arises: are the structure and dynamics of Lajes Reservoir assemblages similar to those in other large river impoundments?
Studies on fish community structure in Brazil are rather scarce. Most research has been done in large rivers impoundment. The present study aims to describe fish assemblages and their spatial variation in Lajes Reservoir, search for eventual environmental influences on fish distribution, and make comparisons with other South American reservoirs.

\section{METHODOLOGY}

\section{Study area}

Lajes Reservoir (Lat. 22 $42^{\prime}-22^{\circ} 50^{\prime}$ 'S; Long. $43^{\circ} 53^{\prime}-44^{\circ} 05^{\prime} \mathrm{W}$ ) was built for hydroelectric purposes in the beginning of last century. It is a $30 \mathrm{~km}^{2}$ impoundment at a crest height of $415 \mathrm{~m}$ above sea level. The artificial lake is fed by headwaters of the partially diverted Piraí River and other small streams draining the slopes of Serra do Mar. It is an oligotrophic lake which presents the unique characteristic of high water quality due to the well-preserved Atlantic Forest surrounding and provides part of the water supply to Rio de Janeiro.

The study area (Fig. 1) was divided into three zones for spatial comparisons: 1, Upper Zone near reservoir headwaters, at the entrance of the main tributaries. The slope is mainly plain with a few steep areas. Depth is lower compared to other zones, and the marginal area is frequently colonized by aquatic macrophytes. Next is the Middle Zone, located between the Upper and Lower Zones, being the largest area, comprising a great number of bays and several islands and exitless waterways. Finally, the lower zone is situated near the dam, where sharp slopes and greater depths predominate. 


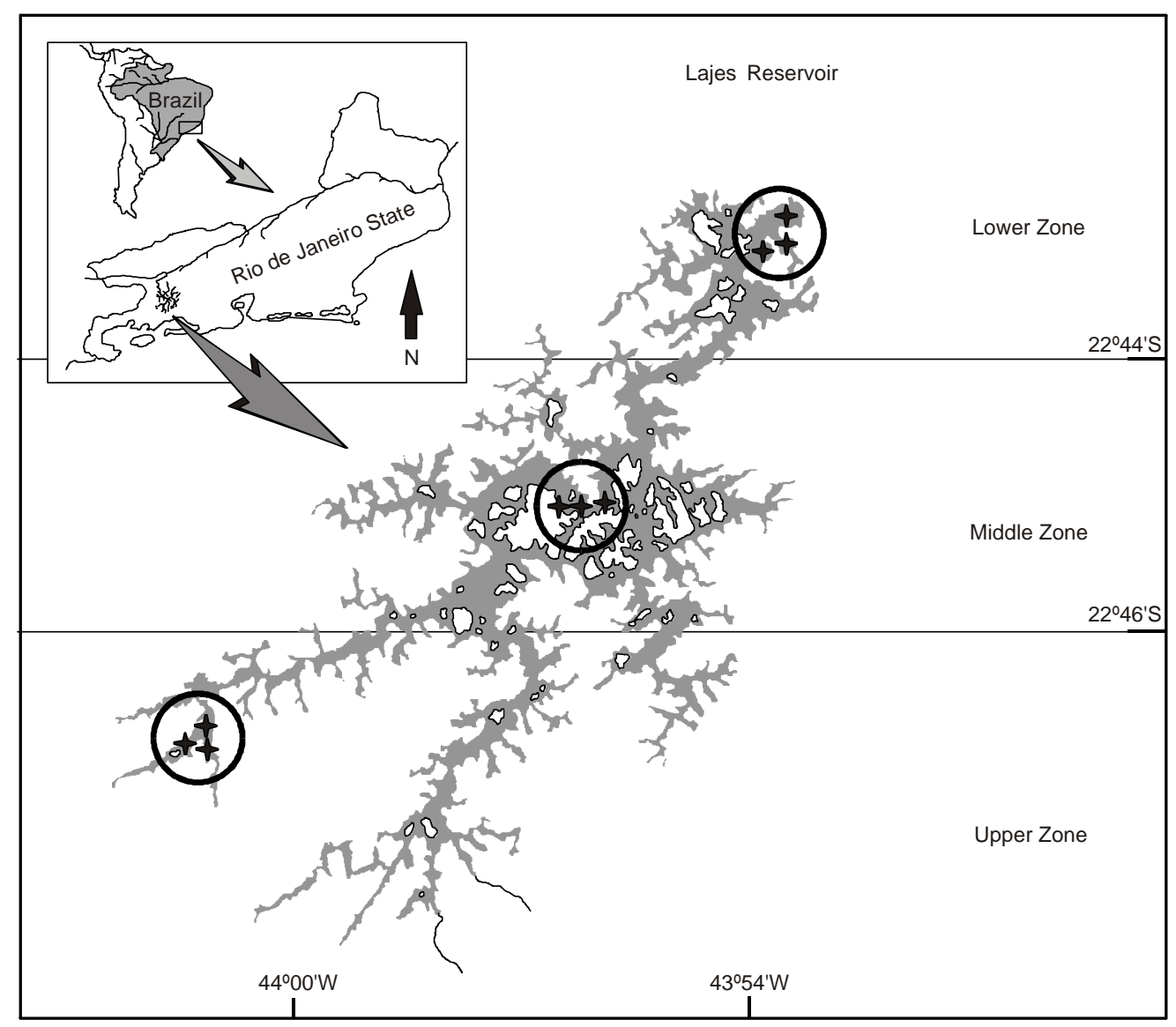

Fig. 1 - Study area, Lajes Reservoir with zones (upper, middle, and lower) and sampling sites (+).

\section{Sampling program}

Sampling was performed from January to December 1994 in the three reservoir zones. Gillnets $50 \mathrm{~m}$ long and $3 \mathrm{~m}$ in height were used with mesh size ranging from 25 to $45 \mathrm{~mm}$ between adjacent knots were left for 12 hours in the water. The nets were set up at sunset and retrieved in the morning of the following day. One side of the nets were attached to the margin and the other was anchored in greater depths. Gillnet catch (number and biomass) was standardized to a common unit of effort (value $/ 100 \mathrm{~m}^{2}$ gillnet/hour). Environmental variables of temperature $\left({ }^{\circ} \mathrm{C}\right), \mathrm{pH}$, conductivity $(\mu \mathrm{S} /$ $\mathrm{cm})$, and transparency $(\mathrm{m})$ were measured at each sampling, while water level data was supplied by the electric company's own meteorological records.

Fishes were identified following the compilation of Fowler $(1948,1950,1951,1954)$ and Britski (1970), or by consulting specialists and museum curators. All the specimens were counted, weighed, and measured for total length. Part of the material was fixed in formalin $10 \%$ and preserved in ethanol $70 \%$.

\section{Data analyses}

Spatial and seasonal comparison of capture per unit effort (CPUE), fish abundance (number and biomass), and environmental variables were performed for the three zones and for each month, respectively. Raw data (biotic and abiotic) were log transformed $\log _{10}(x+1)$ to address homocedastic and normality's parametric statistical tests requirements. Two-way analyses of variance (ANOVA) were used to compare averages and an "a posteriori" Tukey test was applied whenever $\mathrm{H}_{\mathrm{o}}$ was rejected. Multivariate cluster analysis, using Ward's method and squared Euclidian distance, and principal component analysis (PCA) were performed to detect fish assemblage patterns. 


\section{RESULTS}

\section{Environmental factors}

Significant spatial and seasonal differences were detected in abiotic factors of temperature, $\mathrm{pH}$, and transparency (Table 1). Temperature and $\mathrm{pH}$ were higher in summer and lower in winter, while transparency and water level showed the opposite (Fig. 2). Spatially, these differences were less conspicuous, and Tukey test only detected significant differences for temperature, with the middle zone presenting higher values, and upper zone lower values. Water level were significantly higher in April-July and lower in November-February.

Between-zone seasonal comparisons showed that temperature was higher in March-May and lower in June-September in the upper zone, while middle and lower zones showed a more gradual variation over the year. Values of $\mathrm{pH}$ also changed in the same way, with more conspicuous shifts in the upper zone, with higher averages in OctoberMay and lower ones in June/September. For transparency, no defined seasonal patterns in the three zones was observed.

TABLE 1

F-values from ANOVA and averages values + standard deviations for environmental variables in the Lajes Reservoir, Jan-Dec, 1994.

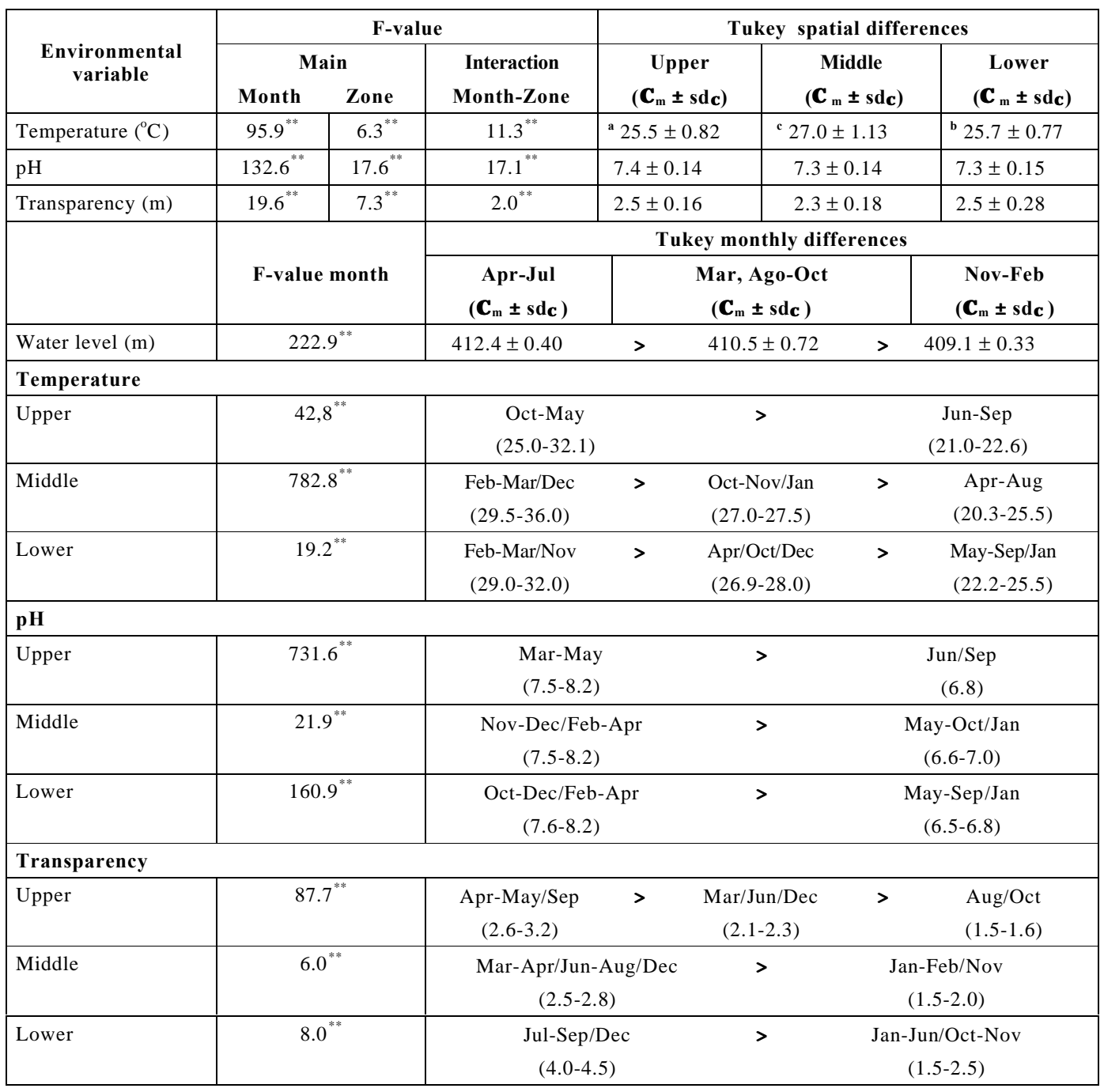




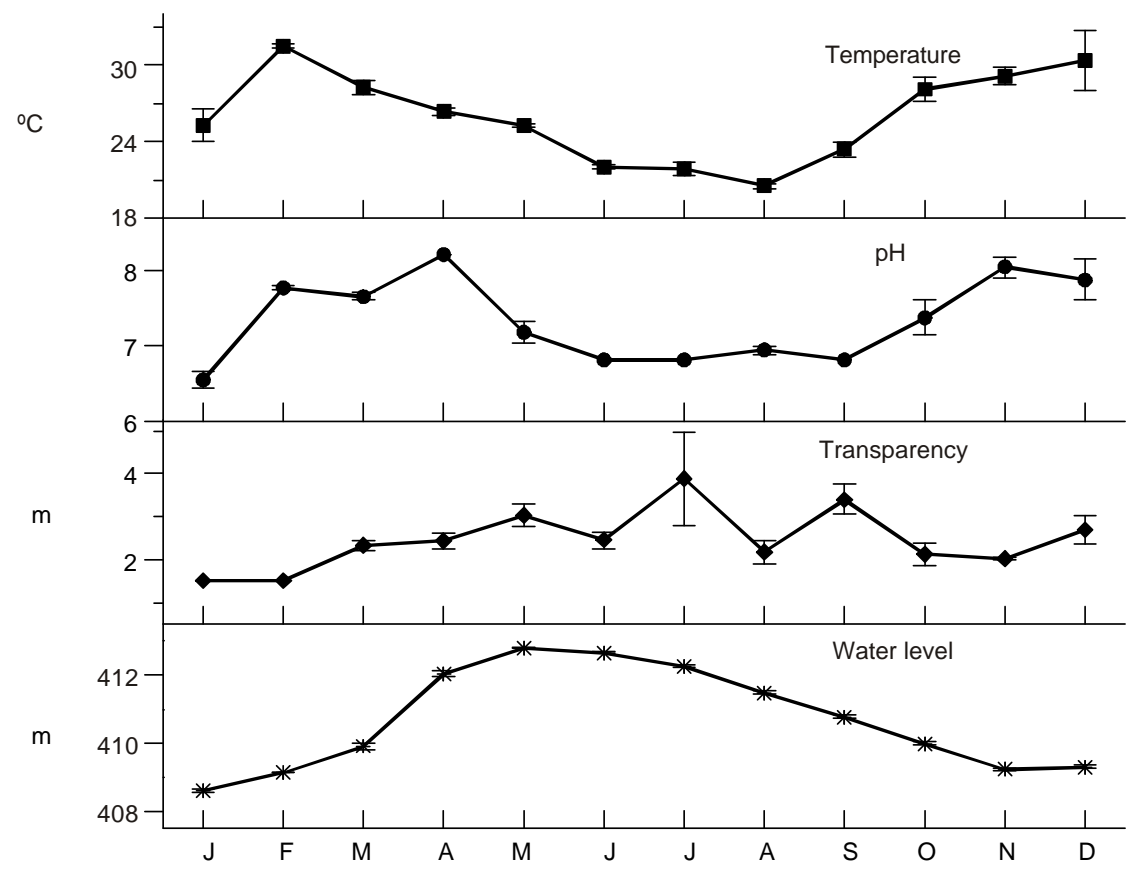

Fig. 2 - Monthly variation in environmental variables in the Lajes Reservoir, Jan-Dec, 1994.

\section{Fish composition}

A total number of 5,089 fishes weighing $1,011.73 \mathrm{~kg}$ was caught in 119 samples, comprising 15 species, 14 genera, and 9 families (Table 2). Characiformes was the most diverse group, represented by 6 species and amounting to $40 \%$ of the total number of fish species, while Siluriformes, with 5 species, totaling $33.3 \%$. These two groups were comprised exclusively by native species, while Perciformes was essentially constituted by nonindigenous species, such as Cichla monoculus and Tilapia rendalli.

\section{Fish community structure}

The eight most abundant fish species represented $97.23 \%$ of the total number and $93.75 \%$ of total weight. Siluriformes represented $89.1 \%$ of total number and $89.9 \%$ of total weight, while Characiformes only contributed $8.8 \%$ and $5.91 \%$, respectively. The remaining species showed only minor contributions in both number and biomass (Table 3).

L. spixii was the most abundant species, contributing $83.3 \%$ of number and $81 \%$ of biomass. All other fish species showed lower than $3 \%$ and
$4 \%$ respectively in number and weight of total fishes. Introduced species $C$. monoculus and $T$. rendalli contributed with less than $1 \%$ of relative abundance. Overall CPUE were 2.4 fishes $/ 100 \mathrm{~m}^{2}$ gillnet/hr and $0.47 \mathrm{~kg} / 100 \mathrm{~m}^{2}$ gillnet/hr respectively.

Only L. spixii showed frequency of occurrence above $50 \%$ of total samples, followed by Rhamdia parahybae, Geophagus brasiliensis, Hypostomus affinis, and Hoplias malabaricus, which presented FO between $25 \%$ and $50 \%$. All other species occurred only accidentally (FO $<25 \%$ ) (Table 3).

\section{Spatial distribution}

Number of fish, species, and biomass were greater in the upper zone, compared with middle and lower zones ( $p<0.01$ ) (Fig. 3), although some differences in this overall pattern were observed for some species individually.

The most abundant fish species, with each contributing above $1 \%$ of the total number, showed some variation in spatial distribution patterns (Fig.4). L. spixii and R. parahybae were significantly $(\mathrm{p}<0.05)$ more abundant in the upper zone than in middle and lower zones. 
TABLE 2

List of fish species in the Lajes Reservoir, RJ, Brazil, in Jan-Dec, 1994. Orders and family follows Lauder \& Lien (1983).

\begin{tabular}{|c|c|}
\hline \multicolumn{2}{|l|}{ CHARACIFORMES } \\
\hline \multicolumn{2}{|l|}{ ERYTHRINIDAE } \\
\hline Hoplias malabaricus & Bloch, 1794 \\
\hline \multicolumn{2}{|l|}{ CURIMATIDAE } \\
\hline Cyphocharax gilberti & Quoy \& Gaimard, 1824 \\
\hline \multicolumn{2}{|l|}{ ANOSTOMIDAE } \\
\hline Leporinus copelandii & Steindachner, 1875 \\
\hline \multicolumn{2}{|l|}{ CHARACIDAE } \\
\hline Astyanax bimaculatus & Linnaeus, 1758 \\
\hline Astyanax fasciatus parahybae & Eigenmann, 1908 \\
\hline Oligosarcus hepsetus & Cuvier, 1829 \\
\hline \multicolumn{2}{|l|}{ SILURIFORMES } \\
\hline \multicolumn{2}{|l|}{ AUCHENIPTERIDAE } \\
\hline Paracheunipterus striatulus & Steindachner, 1876 \\
\hline \multicolumn{2}{|l|}{ PIMELODIDAE } \\
\hline Pimelodella eigenmanni $^{*}$ & Boulenger, 1891 \\
\hline Rhamdia parahybae & Steindachner, 1876 \\
\hline \multicolumn{2}{|l|}{ LORICARIDAE } \\
\hline Loricariichthys spixii & Steindachner, 1877 \\
\hline Hypostomus affinis & Steindachner, 1876 \\
\hline \multicolumn{2}{|l|}{ CIPRYNODONTIFORMES } \\
\hline \multicolumn{2}{|l|}{ POECILIDAE } \\
\hline Poecilia vivipara $^{*}$ & Bloch \& Scheneider, 1801 \\
\hline \multicolumn{2}{|l|}{ PERCIFORMES } \\
\hline \multicolumn{2}{|l|}{ CICHLIDAE } \\
\hline Cichla monoculus & Bloch \& Scheneider, 1801 \\
\hline Geophagus brasiliensis & Quoy \& Gaimard, 1824 \\
\hline Tilapia rendalli & Boulenger, 1896 \\
\hline
\end{tabular}

* Species captured with cast net or beach seine.

Astyanax fasciatus parahybae, Astyanax bimaculatus, Paracheunipterus striatulus, and $H$. affinis were also more abundant in the upper zone, although no significant differences among the zones were detected. On the other hand, G. brasiliensis showed a similar abundance pattern in the three zones, while Oligosarcus hepsetus were more abundant in lower zone, followed by the upper and middle zones ( $\mathrm{p}>0.05$ ).

All fish but G. brasilensis and O. hepsetus were consistently more frequent in the upper zone, followed by middle and lower zones (Table 4).
These two species did not show differences in occurrence in the three zones. L. copelandii, a reolific species, was the only fish which did not occur in all three zones, being absent in the lower zone.

\section{Influences of environmental variables on fish abundance}

A nonparametric Spearman's correlation test revealed low correlation levels between the eight most abundant fish species and environmental variables. 
TABLE 3

Numbers and frequency of occurrence of fish species in Lajes Reservoir, Jan-Dec, 1994.

\begin{tabular}{|l|c|c|c|c|c|}
\hline \multicolumn{1}{|c|}{ Fish Species } & Number & $\mathbf{\%}$ & Weight (g) & \% & FO (\%) \\
\hline Loricariichthys spixii & 4,237 & 83.3 & 819,328 & 81.0 & 59.7 \\
\hline Astyanax bimaculatus & 133 & 2.6 & 6,144 & 0.6 & 15.1 \\
\hline Paracheunipterus striatulus & 117 & 2.3 & 23,045 & 2.3 & 16.8 \\
\hline Astyanax fasciatus parahybae & 107 & 2.1 & 4,442 & 0.4 & 14.3 \\
\hline Oligosarcus hepsetus & 105 & 2.1 & 12,103 & 1.2 & 22.7 \\
\hline Rhamdia parahybae & 93 & 1.8 & 38,562 & 3.8 & 38.7 \\
\hline Hypostomus affinis & 85 & 1.7 & 28,672 & 2.8 & 31.1 \\
\hline Geophagus brasiliensis & 71 & 1.4 & 16,177 & 1.6 & 31.1 \\
\hline Cyphocharax gilberti & 49 & 0.9 & 8,008 & 0.8 & 16.8 \\
\hline Hoplias malabaricus & 46 & 0.9 & 29,077 & 2.9 & 28.6 \\
\hline Cichla monoculus & 32 & 0.6 & 16,312 & 1.6 & 15.1 \\
\hline Tilapia rendalli & 7 & 0.2 & 2,560 & 0.3 & 5.0 \\
\hline Leporinus copelandii & 6 & 0.1 & 7,293 & 0.7 & 4.2 \\
\hline Total & $\mathbf{5 , 0 8 9}$ & & $\mathbf{1 , 0 1 1 , 7 3 2}$ & & \\
\hline
\end{tabular}

The $\mathrm{pH}$ was negatively correlated with abundance of $G$. brasiliensis $(-0.138)$ and total fish weight $(-0.144)(\mathrm{p}<0.05)$. Transparency was negatively correlated with abundance of $O$. hepsetus $(-0.185)$. All the other combinations between environmental variables and fish species abundance were not significantly correlated.

\section{Multivariate analysis}

Hierarchical cluster analysis of the 119 samples yielded 3 distinct groups at less than $10 \%$ rescaled Euclidean distance. A dendogram codified by zones and months is showed in Fig. 5. Cluster 1 comprises a large number of samples from all three zones; in cluster 2 samples from the lower zone predominate while cluster 3 is formed mainly of upper zone samples. Samples labeled by month did not formed any cluster, which indicated that there is no temporal pattern in fish occurrence.

Principal Component Analysis (PCA) yielded 3 components with eigenvalues higher than 1 , explaining $64.8 \%$ of the total variance, but only components 1 and 2 explained $32.7 \%$ and $18.3 \%$, respectively. Component 1 separated higher abundance of L. spixii, A. bimaculatus, and O. hepsetus on the right side, in opposition to abundance of $G$. brasiliensis and $R$. parahybae on the left side.
Component 2 separated positive values of $A$. fasciatus parahybae, $H$. affinis, and P. striatulus in opposition to G. brasiliensis and A. bimaculatus.

Plots of components 1 and 2 codified by zones showed a clustering of samples from the upper zones in the extreme high and right corner, while in the low-left corner there are mainly samples from the lower zone. Overall, there is no a very clear pattern in zones clustering in a particular position in the graph. Instead, there is a more diffuse pattern of samples from all three zones, but the results from the cluster and PCA analyses closely match, indicating a more defined spatial pattern and a much less defined temporal pattern.

\section{DISCUSSION}

Only 15 species were recorded in Lajes Reservoir, characterizing a remarkably low diversity when compared with the original Paraíba do Sul watershed, from which most Reservoir water comes. The Fowler $(1948,1950,1951,1954)$ compilation recorded 92 freshwater species for the Paraíba do Sul watershed; Araújo et al. (1995) and Araújo (1996) recorded 57 freshwater species for the main channel, while Bizerril (1999) recorded 130 species for the whole watershed, including small tributaries. 

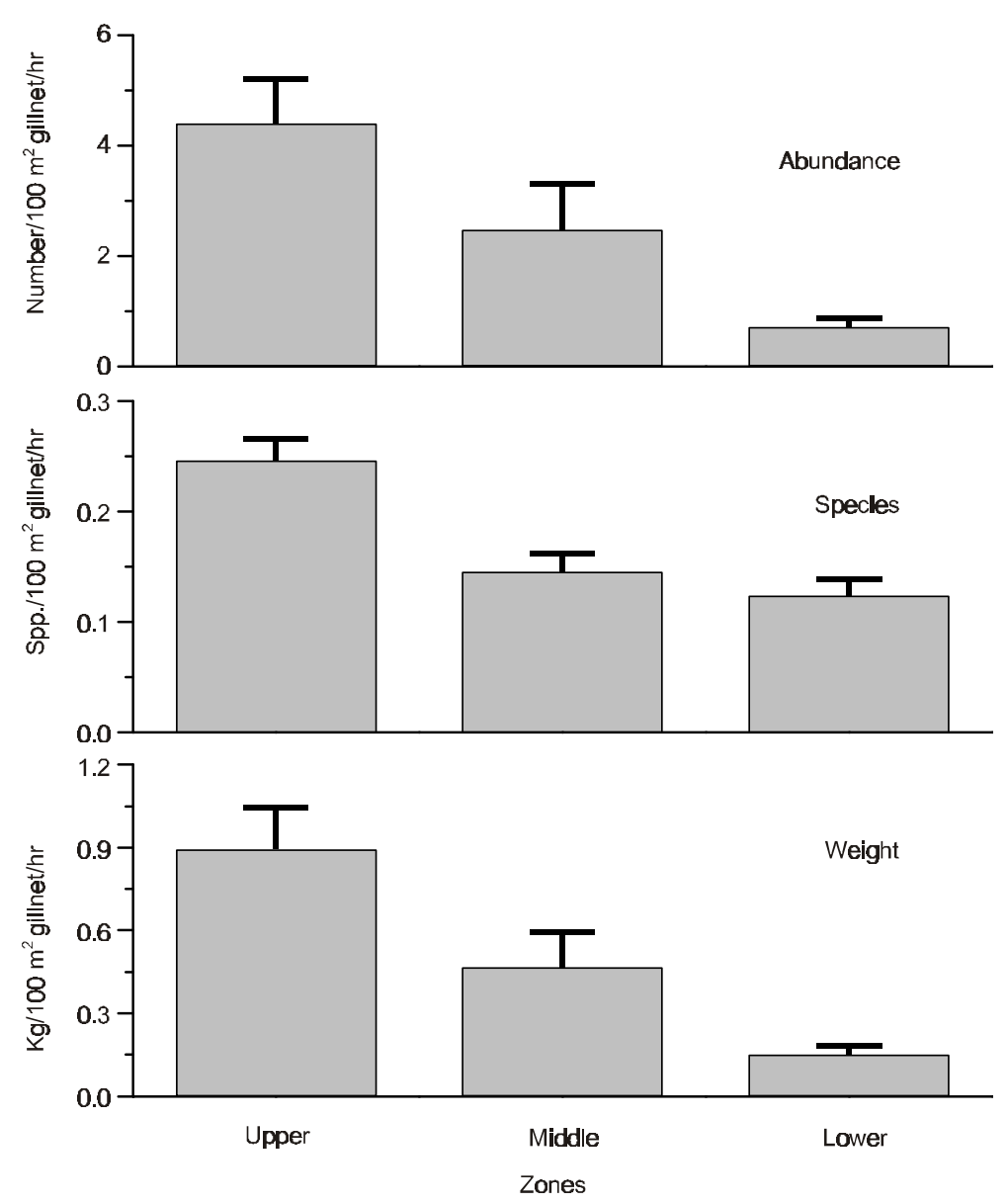

Fig. 3 - Spatial variations in number of fish, species, and biomass in the Lajes Reservoir, Jan-Dec, 1994.

It is accepted that reservoirs typically support fewer fish species than their associated rivers, often as a result of large-scale changes in regimes of temperature, turbidity, flow, allochthonous nutrient inputs, and availability of food resources (Williams et al., 1998). Diversity in Lajes Reservoir is considerable smaller than Barra Bonita (35 species) (Castro, 1997) and Jurumirim impoundments (28 species) (Henry \& Nogueira, 1999), two reservoirs also located in Southeast Brazil, in the same kind of ecoregion, but damming much larger rivers. As there are no big tributaries of Lajes which could allow fish migrations between lentic and lotic systems, this could limit fish diversity.

The Otophysi group represented by Characiformes and Siluriformes contributed over $70 \%$ of the total number of species. According to Britski
(1994) and Bizerril (1999), Siluriformes and Characiformes constitute about $90 \%$ of the diversity in Paraíba do Sul watershed with Siluriformes being the major group, contributing about $55 \%$ of all species. In Lajes to Reservoir, Characiformes contributed $40 \%$ fish diversity and Siluriformes, $33.3 \%$. This could be associated with reservoir characteristics like reduced diversity of bottom substrate, with low availability of gravel, stones, and rocks, which could affect more intensively the Siluriformes, a group closed related to the substrate, than the Characiformes, a more water column dwelling species. Overall, the proportion of Characiformes/Siluriformes in reservoirs are rather well balanced, as in Itaipu (Cecilio et al., 1997), Segredo, and Foz de Areia (Agostinho \& Gomes, 1997) impoundments. 

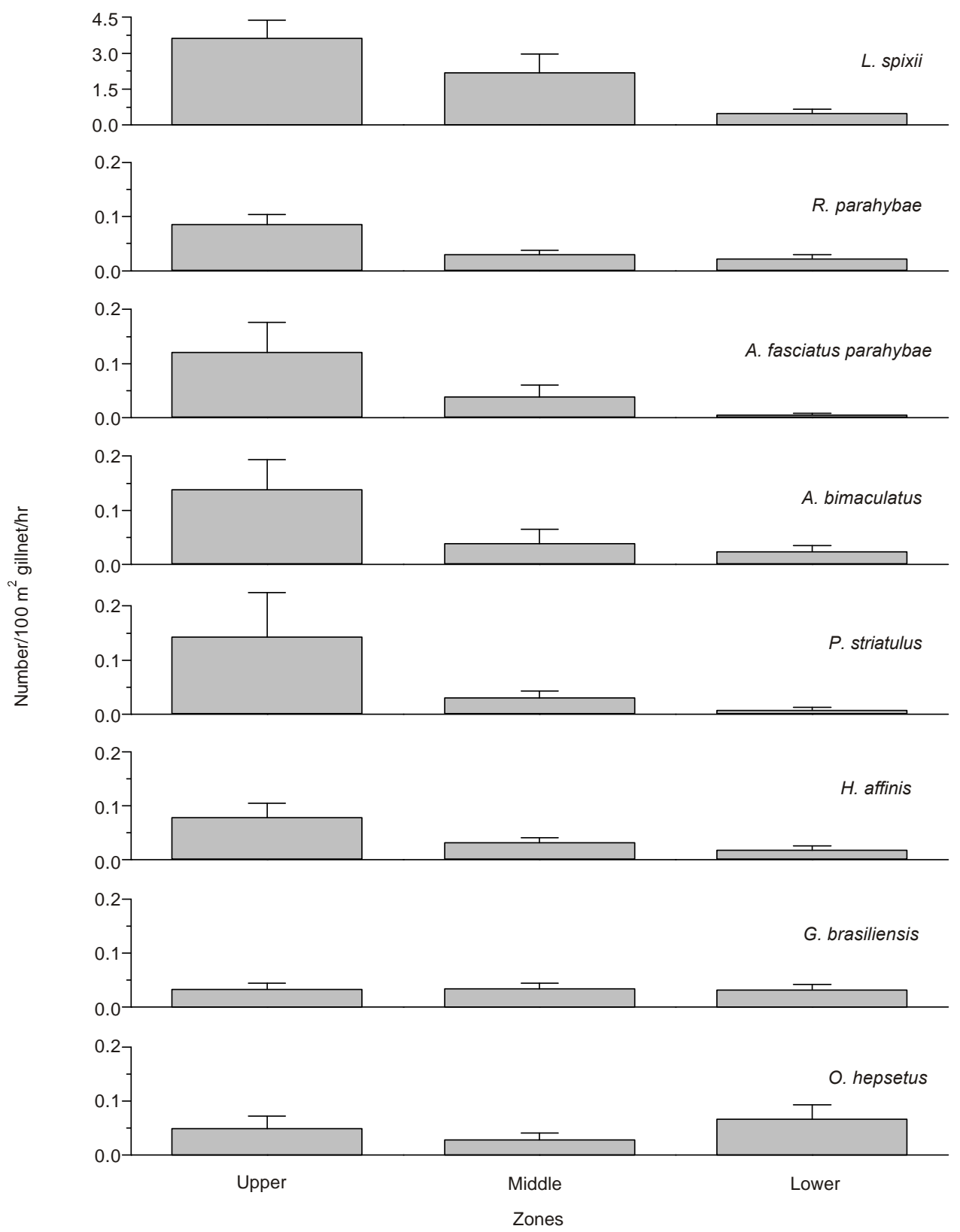

Fig. 4 - Spatial variations in CPUE (catches per unit effort) of the most abundant fish in the Lajes Reservoir, Jan-Dec, 1994.

On the other hand, in the natural lake Batata (Halbot, 1995), Characiformes (54\%) were more diverse than the Siluformes (38\%) in relation to the total number of species.

Part of the fish community in the reservoir could be poorly represented due to fishing equip- ment limitations, since gillnets could be less efficient for small-sized and bottom dwelling species. The absence or reduced participation of small-sized species like Poecilidae, Trichomycteridae and Tetragonopterinae, which are abundant in small rivers and streams (Araújo et al., 1995; Bizerril, 
1999) associated with low depth in small water systems is well-known. Increased depth in a reservoir acts as a barrier for small fish, since shelter availability from predation by larger fishes is enhanced (Agostinho et al., 1997).

L. spixii was the dominant species in Lajes Reservoir, showing that the impoundment, where fine substrate predominates, is very favorable for this species. On the other hand, the Loricariid $H$. affinis, a highly abundant species in Paraíba do Sul River (Araújo, 1996) where there are much hard substrates for its algae epilitic habits, showed relatively low abundance in the reservoir. Caramaschi (1994) recorded that Hypostomus spp. are associated with imbedded rock formation and runs, while Loricarichtys spixii is more associated with sand-muddy substrates and pool habitats. The presence of dermal armour and stout spines at dorsal and pectoral fins reduced predation on these species (Lowe-McConnell, 1975), and associated with detritivore/iliophagic habits also contributes to their success in using available resources in the reservoir.

Low abundant reolific $L$. copelandii and $C$. gilberti occurred mainly in the upper zone, and the lack of Prochilodus spp., a common species in Paraíba do Sul River, suggest that impoundment environmental conditions are less suitable for these species. Intro- duced Cichla monoculus and T. rendalli low abundance contrasts with findings of Oliveira et al. (1986), in which these species rank as most abundant. This could be explained because in that work additional equipment besides gillnets, such as mesh trays, casting nets, and seines was used. Additionally, increasing water level fluctuation dictated by hydroelectric demand could be contributing to decreasing abundance of these species, since C. monoculus is associated with forage species like Tilapia, a allochthonous vegetation-dependent species (Williams et al., 1998). Cichlids species are peculiar for their well-developed vision (Goldstein, 1973), which could also contribute to ineffectiveness of the gillnets.

Environmental variables did not predict fish abundance in this study. Seasonal temperatures are more likely to contribute, with pulse abundance of young-of-the-year fish less likely to be caught by gillnets. Seasonal water level variations according to power station demand, exposing extensive areas of littoral margins in late Spring/Summer, the most intense fish spawning period, increase egg and larval mortality and predation, and decrease available shelters and food from flooded marginal vegetation. Highly significant spatial difference in transparency and $\mathrm{pH}$ according to ANOVA did not match Tukey test results, which could be due to high interaction with months.

TABLE 4

Frequency of occurrence for the most abundant fish species by zones in the Lajes Reservoir, Jan-Dec, 1994.

\begin{tabular}{|l|c|c|c|}
\hline \multirow{2}{*}{\multicolumn{1}{|c|}{ Fish species }} & \multicolumn{2}{c|}{ FO (\%) per Zone } \\
\cline { 2 - 4 } & Upper & Middle & Lower \\
\hline Loricariichthys spixii & 80.0 & 48.7 & 24.4 \\
\hline Rhamdia parahybae & 62.9 & 33.3 & 17.8 \\
\hline Hypostomus affinis & 48.6 & 30.8 & 24.4 \\
\hline Hoplias malabaricus & 42.9 & 20.5 & 8.9 \\
\hline Cyphocharax gilberti & 34.3 & 10.3 & 31.1 \\
\hline Geophagus brasiliensis & 28.6 & 33.3 & 6.7 \\
\hline Paracheunipterus striatulus & 28.6 & 18.0 & 8.9 \\
\hline Cichla monoculus & 25.7 & 12.8 & 6.7 \\
\hline Astyanax fasciatus parahybae & 25.7 & 12.8 & 22.2 \\
\hline Oligosarcus hepsetus & 22.9 & 20.5 & 13.3 \\
\hline Astyanax bimaculatus & 22.9 & 10.3 & 2.2 \\
\hline Tilapia rendalli & 8.6 & 5.1 & - \\
\hline Leporinus copelandii & 8.6 & 5.1 & $\mathbf{4 5}$ \\
\hline Total of samples & $\mathbf{3 5}$ & $\mathbf{3 9}$ & \\
\hline
\end{tabular}




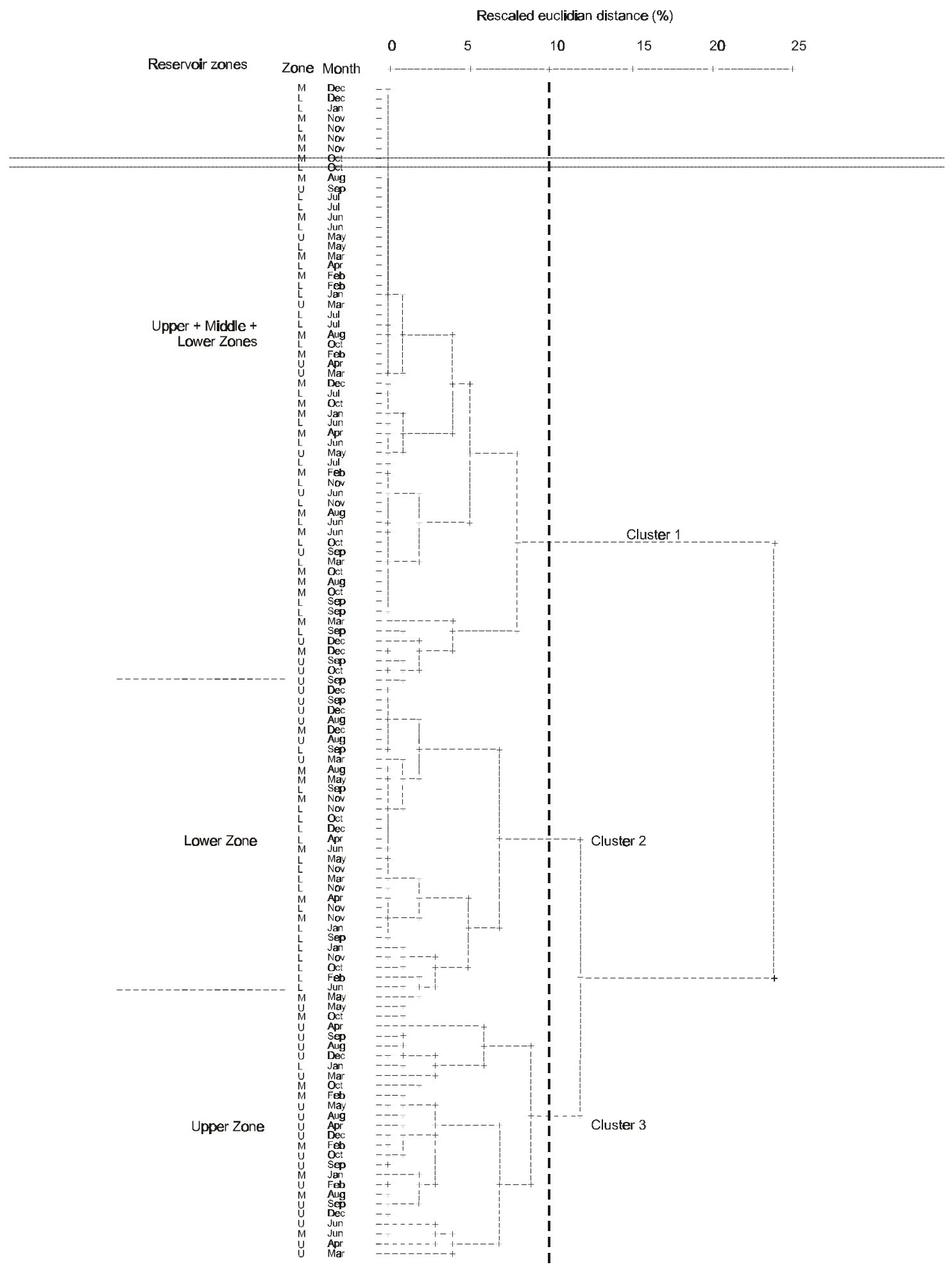

Fig. 5 - Hierarchical clustering for fish abundance in Lajes Reservoir, labeled by zones and sampling months. Zone codes: L - Lower Zone; M - Middle Zone; U - Upper Zone. 


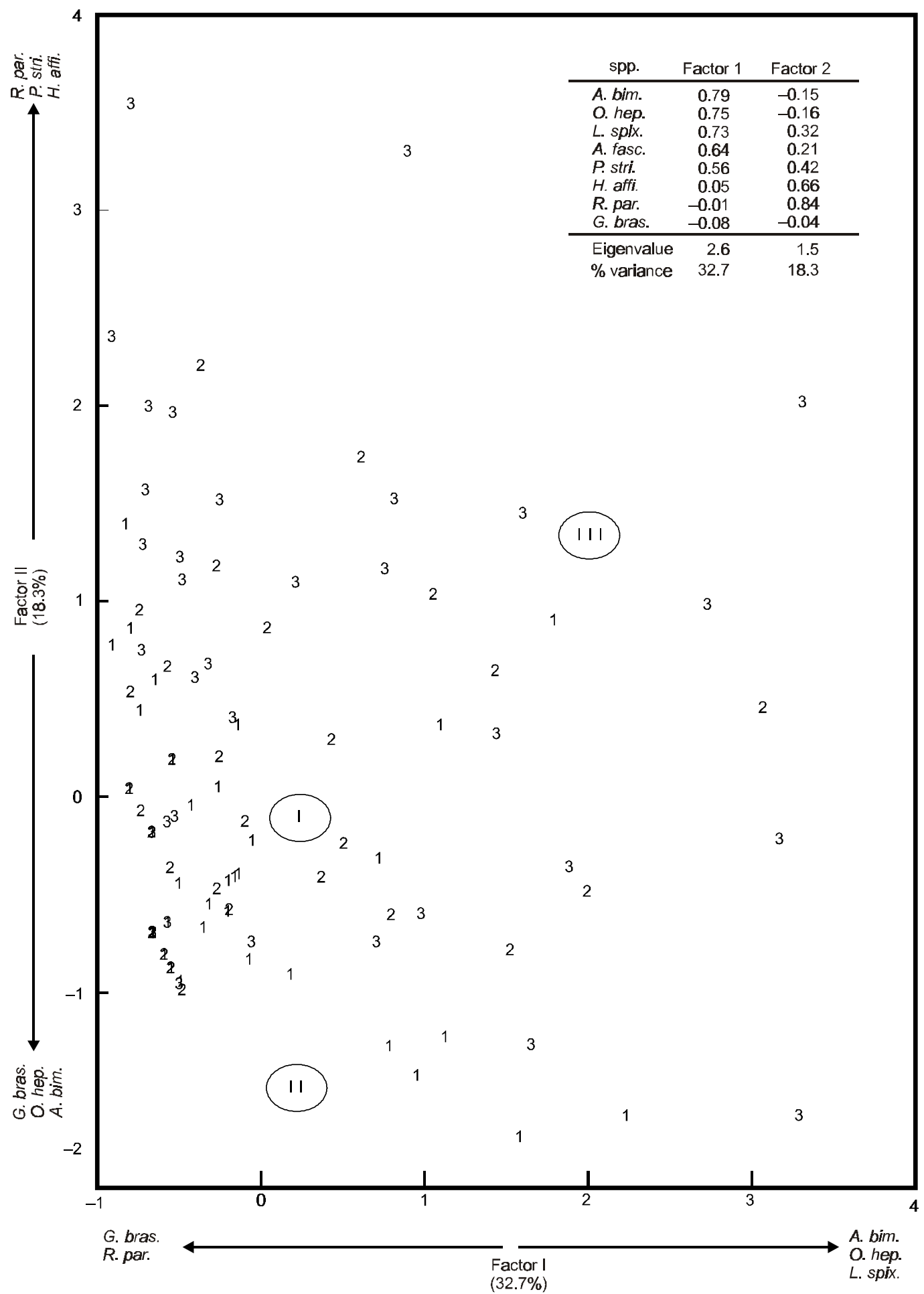

Fig. 6 - Ordination diagram on the axis loads from principal component analysis of fish abundance in Lajes Reservoir. Zones labels: 1 - Lower Zone; 2 - Middle Zone; 3 - Upper Zone; I, II and III correspond to group results from cluster analysis. 
Additionally, the range values for these factors are well within the level of fish tolerance.

Comparatively higher availability of food and habitat diversity in the upper zone is the probable cause of greater fish abundance and diversity, when compared with lower and middle zones. Resources in upper Lajes are also favored by most of its tributaries which carry into the reservoir allochthonous materials, and increase habitat diversity for fish assemblages. Lower and middle zone comparatively sloped margin gradients are more restrictive as fish habitats.

Overall fish abundance, number of species, and biomass were conspicuously higher in the upper zone, although slight differences in fish composition can be discerned. Multivariate cluster and Principal Component Analyses showed closely related results. Overall, a high overlap of most species co-occurring in all three zones was showed but slight variation in this spatial pattern was observed. Abundant L. spixii, O. hepsetus, and $A$. bimaculatus occurred in all zones, although predominating in the upper reservoir, as indicated by component 1 and cluster $1 ; R$. parahybae, $H$. affinis and $P$. striatulus are more likely to occur in high abundance only in the upper zone, as indicated by cluster 3 and high scores in component 2. On the other hand, G. brasiliensis is the most evenly distributed species among the zones, with no spatial difference in its occurrence in Lajes Reservoir, as indicated by cluster 2 and by the lowest scores in both components. The Lajes Reservoir ichthyofauna, with low diversity, high proportion of Characiforms, and few reolific species configure a situation closer to that of natural tropical lakes and small reservoirs than large river impoundments.

Aknowledgments - This study was make possible thanks to financial aid from the Brazilian National Agency for Research Development (CNPq). We also thank LIGHT Serviços de Eletricidade S.A., owner of the reservoir, and specially to Dr. Sebastião Paulino and Ricardo Bichara for logistic and infrastructural support.

\section{REFERENCES}

Agostinho, A. A. \& GOMES, L. C., 1997, Manejo e monitoramento de recursos pesqueiros: perspectivas para o reservatório de Segredo. In: A. A. Agostinho \& L. C. Gomes (eds.), Reservatório de segredo - bases ecológicas para o manejo. EDUEM, Maringá, pp. 275-292.
Agostinho, A. A., FERRETTI, C. L. M., GOMES, L. C., HAHN, N. S., SUZUKI, H. I., FUGI, R. \& ABUJANRA, F., 1997, Ictiofauna de dois reservatórios do rio Iguaçu em diferentes fases de colonização: Segredo e Foz de Areia. In: A. A. Agostinho \& L. C. Gomes (eds.), Reservatório de segredo - bases ecológicas para o manejo. EDUEM, Maringá, pp. 319-364.

ARAÚJO, F. G., 1996, Composição e estrutura da comunidade de peixes do médio e baixo rio Paraíba do Sul, RJ. Rev. Brasil. Biol., 56(1): 111-126.

ARAÚJO, F. G., SANTOS, A. C. A. \& SIMONI, M. R. F., 1995, Variações espacial e temporal da comunidade de peixes do médio e baixo rio Paraíba do Sul, RJ. Rev. Univ. Rural, Sér. Ciênc. da Vida, 17(2): 61-73.

BIZERRIL, C. R. S. F. A., 1999, Ictiofauna da Bacia do Rio Paraíba do Sul. Biodiversidade e padrões Biogeográficos. Braz. Arch. of Biol. and Techn., 42(2): 233-250.

BRITSKI, H. A., 1970, Peixes de água doce do Estado de São Paulo - sistemática. In: Com. Interest. da Bacia Paraná-Uruguai. Poluição e Piscicultura. São Paulo, pp. 79112.

BRITSKI, H. A., 1994, A fauna de peixes brasileiros de água doce e o represamento de rios. In: Comase/Eletrobrás. Seminário sobre fauna aquática e o setor elétrico brasileiro, 1: 23-30.

CARAMASCHI, E. P., 1994, Aspectos da distribuição dos peixes de água doce. In: Comase/Eletrobrás. Seminário sobre fauna aquática e o setor elétrico brasileiro, 1 : 1822 .

CASTRO, A. C. L. de, 1997, Aspectos ecológicos da comunidade ictiofaunística do reservatório de Barra Bonita, SP. Rev. Brasil. Biol., 57(4): 665-676.

CECILIO, E. B., AGOSTINHO, A. A., JÚlio JR., H. F. \& PAVANELLI, C. S., 1997, Colonização ictiofaunística do reservatório de Itaipu e áreas adjascentes. Rev. Brasil. Zool., Curitiba, 14(1): 1-14.

FOWLER, H. W., 1948, Os peixes de água doce do Brasil. I. Arq. Zool., São Paulo, 6: i-xii, 1-204.

FOWLER, H. W., 1950, Os peixes de água doce do Brasil. I. Arq. Zool. São Paulo, 6: i-xii, 205-404.

FOWLER, H. W., 1951, Os peixes de água doce do Brasil. I. Arq. Zool. São Paulo, 6: i-xii, 405-625.

FOWLER, H. W., 1954, Os peixes de água doce do Brasil. II. Arq. Zool., São Paulo, 9: i-xii, 1-400.

GOLDSTEIN, R. J., 1973, Cichlids of the world. T. F. H. Publications, Inc. Ltd., New Jersey, 382p.

HALBOT, D. A., 1995, Estrutura da comunidade de peixes do lago Batata (Rio Trombetas, PA). Dissertação de Mestrado, UFRJ, Rio de Janeiro, 134p.

HENRY, R. \& NOGUEIRA, M. G., 1999, A Represa de Jurumirim. In: R. Henry (ed.), Ecologia de reservatórios: estrutura, função e aspectos sociais. Fapesp-Fundibio, São Paulo, pp. 651-686. 
KEAST, A., 1978, Trophic and spatial interrelationship in the fish species of an Ontario temperate lake. Env. Biol. Fish., 3: 7-31.

LAUDER, G. V. \& LIEN, K. F., 1983, The evolution and reationship of Actinopterygii fishes. Bull. Mus. Comp. Zool., 150(3): 95-197.

LOWE-McCONNELL, R. H., 1975, Fish Communities in Tropical Freshwaters. Longman Inc., New York, 283p.

OLIVEIRA, S. L. de, MENDES, Z. C., CRISÓSTOMO, L. C. \& ARAÚJO, F. G., 1986, Resultados preliminares do levantamento ictiológico na represa de Ribeirão das Lajes, Estado do Rio de Janeiro. Public. Avulsas Mus. Nac. do Rio de Janeiro (65): 87-90.
WELCOMME, R. M., 1979, Fisheries ecology of floodplains rivers. Longman, $317 \mathrm{p}$.

WILLIAMS, J. D., WINEMILLER, K. O., TAPHORN, D. C. \& BALBAS, L., 1998, Ecology and status of piscivores in Guri, an oligotrophic tropical reservoir. North American Journal of Fisheries Management, 18: 274-285. 